\title{
KID CROP KAMBING KACANG (Capra Hircus) di KABUPATEN KONAWE UTARA
}

\author{
Lena Wati ${ }^{1}$, Rahim Aka ${ }^{1}$ dan Takdir Saili ${ }^{1 *}$ \\ ${ }^{1)}$ Jurusan Peternakan Fakultas Peternakan Universitas Haluoleo \\ *E-mail: takdir69@yahoo.com
}

\begin{abstract}
ABSTRAK
Salah satu variabel penentu dalam mengukur perkembangan populasi ternak di suatu wilayah adalah jumlah kelahiran anak ternak. Pada ternak kambing dan domba, produktivitas seekor induk dapat diketahui dengan menggunakan indikator nilai panen cempe. Informasi tentang nilai panen cempe, khususnya ternak Kambing Kacang di Kabupaten Konawe Utara masih kurang sehingga perlu dilakukan penelitian untuk memperoleh data tersebut. Tujuan penelitian ini adalah untuk mengetahui nilai panen cempe Kambing Kacang di Kabupaten Konawe Utara. Lokasi penelitian ditentukan dengan menggunakan dua metode, yaitu metode stratified sampling dan purposive sampling. Sedangkan penentuan responden pada desa terpilih digunakan metode sensus. Hasil penelitian menunjukkan bahwa nilai rataan panen cempe Kambing Kacang di Kabupaten Konawe Utara adalah 167,71\% dengan interval kelahiran sebesar 8,61 bulan dan jumlah anak sekelahiran sebesar 1,36 ekor, sedangkan mortalitasnya mencapai $13,96 \%$. Kesimpulan dari penelitian ini adalah produktivitas ternak Kambing Kacang di Kabupaten Konawe Utara masih cukup baik berdasarkan variable nilai panen cempenya.
\end{abstract}

Kata Kunci: Kambing Kacang, Cempe, Kid Crop, Konawe Utara.

\begin{abstract}
One of determined variable to evaluate population growth of livestock in certain area is the number of offspring produced in certain period. On goat and lamb production, productivity could be determined using kid crop variable. Information related to kid crop, especially kid crop of Kacang goat in Konawe Utara District was limited, hence the research on this issue was need for providing the related data. The objective of this research was to determine kid crop of Kacang goat in Konawe Utara District. The location was sequentially established using stratified and purposive sampling methods, while respondent on the named village was established using counting method. The results showed that kid crop of Kacang goat in Konawe Utara District was $167,71 \%$ with 8,61 month of kidding interval and 1,36 kids of litter size, whereas mortality was $13,96 \%$. In conclusion, Kambing goat productivity in Konawe Utara District was still good based on the kid crop variable.
\end{abstract}

Key words: Kacang goat, Kid, Kid Crop, Konawe Utara.

\section{PENDAHULUAN}

Sulawesi Tenggara merupakan salah satu daerah di kawasan timur Indonesia yang memiliki prospek cukup cerah dalam upaya pengembangan ternak ruminansia, khususnya ternak kambing. Hal ini didukung oleh sumber daya alam yang cukup potensial dan dapat dikatakan sebagai kawasan yang belum dikelola secara optimal. Umumnya ternak kambing yang banyak dipelihara oleh petani peternak di Sulawesi Tenggara adalah Kambing Kacang. Populasi ternak kambing di Sulawesi Tenggara memiliki 
sebaran yang berbeda-beda pada setiap daerah. Hal ini disebabkan karena adanya perbedaan topografi, kondisi iklim dan keadaan sosial budaya masing-masing daerah. Kabupaten Konawe Utara adalah salah satu kabupaten di Sulawesi Tenggara yang mempunyai populasi ternak kambing kacang cukup banyak.

Pada umumnya sistem pemeliharaan ternak kambing yang dilakukan oleh petani peternak di Kabupaten Konawe Utara masih dilakukan secara tradisional yaitu ternak kambing dikandangkan dan juga digembalakan pada jam-jam tertentu (semi intensif). Hal ini kebanyakan dipengaruhi oleh adanya kebiasaan penduduk setempat, dan tersedianya lahan atau padang penggembalaan yang cukup luas. Rendahnya keterampilan dan terbatasnya kemampuan peternak dalam mengadopsi teknologi peternakan menyebabkan produktivitas ternak kambing menjadi rendah(BPS Sultra, 2009).Jenis pakan yang sering dikonsumsi oleh ternak kambing di daerah ini adalah rumput alam, daun gamal dan limbah pertanian, seperti kulit pisang, pelepah pisang, jerami padi dan daun kelapa sawit.

Rendahnya keterampilan dan terbatasnya kemampuan peternak dalam mengadopsi teknologi peternakan menyebabkan produktivitas ternak kambing menjadi rendah(BPS Sultra, 2009).Kurangnya informasi tentang produktivitas ternak kambing, khususnya nilai panen cempe di Konawe Utara, maka perlu dilakukan penelitian tentang nilai panen cempe di Kabupaten Konawe Utara.

\section{MATERI DAN METODE}

\section{Populasi dan Sampel Penelitian}

Populasi penelitian adalah petani peternak yang memelihara ternak kambing yang sudah pernah melahirkan minimal 2 kali.

Sampel penelitian adalah petani peternak yang terdapat di tiga kecamatan lokasi penelitian yaitu, Kecamatan Lasolo sebanyak 21 responden, Kecamatan Molawe sebanyak 15 responden, dan Kecamatan Asera sebanyak 23 responden.

\section{Teknik Penentuan Lokasi dan Penarikan Sampel}

Penentuan lokasi penelitian di tingkat kabupaten digunakan metode stratified sampling yaitu melakukan stratifikasi jumlah ternak pada tujuh kecamatan ke dalam kategori populasi tinggi, sedang, dan rendah. Selanjutnya di dalam setiap kategori dipilih satu kecamatan secara random. Sedangkan penentuan lokasi di tingkat kecamatan dilakukan secara purposive sampling dengan cara memilih desa yang terbanyak populasi ternak kambingnya dalam suatu kecamatan. Setiap kecamatan diwakili 3-5 desa.

Penentuan strata populasi ini dilakukan dengan cara mencari kisaran populasi ternak kambing tertinggi (PT) dikurangi populasi terendah $(\mathrm{PR})=(\mathrm{K}$ populasi), selanjutnya dibagi 3 sehingga dihasilkan interval strata $(1 / 3 \quad \mathrm{~K})$. Penentuan kisaran strata sebagai sampel yaitu (1) Populasi rendah $=\mathrm{PR}$ s.d PR + $1 / 3 \mathrm{~K}$, (2) Populasi sedang $=\mathrm{PR}+1 / 3 \mathrm{~K}+$ 1 s.d PR + 2/3 K, (3) Populasi tinggi = PR $+2 / 3 \mathrm{~K}+1$ s.d PR + K (Sani, 2008).

\section{Teknik Pengumpulan Data}

Data yang dikumpulkan dalam penelitian ini terdiri atas:

Data primer adalah data yang diperoleh melalui observasi lapangan melalui wawancara dengan peternak (responden) menggunakan bantuan perangkat kuisioner yang telah disiapkan. Data sekunder yaitu data yang diperoleh dari instansi terkait 
yaitu Biro Pusat Statistik Kabupaten Konawe Utara.

Variabel Penelitian yang diamati dalam penelitian ini adalah:

1. Kinerja reproduksi yang terdiri atas: jumlah induk, interval beranak, litter size, angka kelahiran cempe, angka kematian cempe.

2. Panen Cempe.

Untuk menghitung panen cempe maka dilakukan pencatatan terhadap induk dan cempe yang lahir sampai dengan umur disapih (90 hari), dihitung dengan menggunakan rumus menurut Widi (2002):

Dimana : IK = Interval Kelahiran.

Panen cempe $=\frac{\{(\text { Jumlah cempe lahir }- \text { [umlahcempe mati }) \times 100 \%\}}{\text { Jcmlak } i n d u k} \times \frac{12}{I K}$

\section{Analisis Data}

Data yang diperoleh (data primer) ditabulasi dan selanjutnya dianalisis secara deskriptif

\section{HASIL DAN PEMBAHASAN}

\section{Kinerja Reproduksi}

Kambing Kacang merupakan jenis kambing yang diketahui memiliki daya adaptasi yang tinggi terhadap kondisi alam sekitarnya, serta memiliki tingkat reproduksi yang tinggi. Selain itu, ternak kambing juga memiliki keistimewaan dibandingkan dengan ternak subtropis lainnya yaitu mampu menghasilkan anak sepanjang tahun atau kemampuan reproduksinya tidak tergantung pada musim (Non Seasional Breeding). Kinerja reproduksi ternak Kambing Kacang pada masing-masing kecamatan yang didapatkan pada penelitian ini dapat dilihat pada Tabel 1.

Tabel 1. Kinerja Reproduksi Kambing Kacang pada Masing-Masing Kecamatan di Kabupaten Konawe Utara

\begin{tabular}{|c|c|c|c|c|c|}
\hline $\begin{array}{l}\text { Variabel yang } \\
\text { Diamati }\end{array}$ & $\begin{array}{c}\text { Strata } \\
\text { Tinggi } \\
\text { (Kec. Lasolo) } \\
\text { ekor } \\
\end{array}$ & $\begin{array}{c}\text { Strata } \\
\text { Sedang } \\
\text { (Kec. Molawe) } \\
\text { ekor } \\
\end{array}$ & $\begin{array}{l}\text { Strata } \\
\text { Rendah } \\
\text { (Kec.Asera) } \\
\quad \text { ekor } \\
\end{array}$ & Total & $\begin{array}{l}\text { Jumlah } \\
\text { Rata-rata }\end{array}$ \\
\hline$\Sigma$ induk beranak & 29 & 21 & 30 & 80 & \\
\hline Jarak kelahiran (Bulan) & 8,58 & 8,56 & 8,68 & 25,82 & 8,61 \\
\hline Litter size 1,44 & 1,17 & 1,48 & 4,09 & 1,36 & \\
\hline$\Sigma$ cempe lahir (1 thn) & 84 & 52 & 86 & 222 & \\
\hline$\Sigma$ cempe yang mati & 17 & 5 & 9 & 31 & \\
\hline Mortalitas cempe (\%) & 20,24 & 9,61 & 10,46 & 40,31 & 13,96 \\
\hline Panen cempe & 163,97 & 138,24 & 200,93 & 503,14 & 167,71 \\
\hline
\end{tabular}




\section{Jumlah Induk}

Jumlah kepemilikan induk Kambing Kacang di lokasi penelitian berjumlah 80 ekor (Tabel 1), dengan jumlah kepemilikan induk tertinggi terdapat pada Kecamatan Asera yaitu sebanyak 30 ekor. Jumlah induk yang melahirkan kembar 2 dan 3 terbanyak terdapat pada Kecamatan Lasolodengan jumlah 13 dan 5 ekor, sedangkan jumlah induk yang melahirkan tunggal tertinggi terdapat pada Kecamatan Molawe yaitu sebesar 16 ekor.

Tingginya jumlah kepemilikan induk yang melahirkan kembar baik kembar 2 maupun kembar 3 pada Kecamatan Lasolo dan Kecamatan Asera dibandingkan dengan Kecamatan Molawedisebabkan pada kedua kecamatan tersebut (Kecamatan Lasolo dan Kecamatan Asera) masih memiliki sumber ketersediaan pakan yang cukup banyak (padang penggembalaan dan lahan perkebunan). Aspek pakan juga mempunyai pengaruh yang sangat besar yaitu sekitar $60 \%$ terhadap produksi ternak kambing, selain faktor lingkungan.

Hasil penelitian yang diperoleh tidak berbeda jauh dengan hasil penelitian yang dilakukan oleh Devendra dan Burns (1994) yaitu persentase kelahiran kembar 2 pada kelahiran pertama sekitar 19\% dan meningkat pada kelahiran kedua menjadi 79\%. Selain itu, kejadian kelahiran kembar pada kambing adalah umum dan kesuburan akan meningkat seiring dengan bertambahnya umur.

\section{Interval Beranak (Kidding Interval)}

Rataan interval beranak ternak kambing pada penelitian ini adalah 8,61 bulan dengan interval beranak terendah terdapat pada Kecamatan Asera sebesar 8,56 bulan diikuti Kecamatan Lasolo 8,58 bulan dan Kecamatan Molawe 8,68 bulan. Interval beranak kambing yang diperoleh pada penelitian ini masih berada pada kisaran normal. Djoharjani et al., (1993) melaporkan bahwa pada kondisi lapangan, interval beranak ternak kambing bervariasi antara 7-12 bulan. Selanjutnya dikemukakan bahwa untuk menempatkan seekor pejantan dalam sekelompok betina sekitar 3 bulan setelah beranak akan mendapatkan interval beranak 8 bulan.

Interval beranak juga mempengaruhi angka panen cempe karena semakin pendek interval beranak maka akan meningkatkan angka panen cempe. Hal ini sesuai dengan pendapat yang dikemukakan oleh Basuki et al.,(1981) bahwa jarak kelahiran dipengaruhi oleh lama bunting dan jarak waktu antara melahirkan dan perkawinan berikutnya (service periode).

\section{Litter size}

Hasil penelitian menunjukkan bahwa rataan litter size ternak kambing pada Kecamatan Asera sebesar 1,48. Angka ini lebih tinggi dibandingkan dengan litter size ternak kambing pada Kecamatan Lasolo dan Kecamatan Molawe yang masing-masing 1,44 dan 1,17. Rataan litter size Kambing Kacang di Kabupaten Konawe Utara yaitu sebesar 1,36. Rataan litter size yang diperoleh pada penelitian ini tidak berbeda jauh dengan rataan litter size ternak kambing yang dikemukakan oleh Subandriyo (1986) yaitu sebesar 1,56 untuk Kambing Kacang dan 1,43 untuk kambing Peranakan Etawah (PE).

Kejadian kelahiran kembar pada kambing menunjukkan adanya tingkat kesuburan dan akan meningkat seiring dengan semakin bertambahnya umur. Hal ini sesuai dengan pendapat yang dikemukakan oleh Devandra dan Burns (1994) bahwa kejadian kelahiran kembar pada kambing adalah umum dan kesuburan akan meningkat seiring dengan bertambahnya umur. Kelahiran kembar 2 pada kelahiran pertama yaitu sekitar 19\% dan meningkat pada kelahiran ke 2 yaitu sekitar 79\%. Hal ini dikarenakan adanya pengaruh genetik, kualitas dan kuantitas 
pakan yang tersedia serta bangsa dari ternak tersebut.Beberapa penelitian menyebutkan juga bahwa kembar 2 pada kelahiran pertama yaitu sekitar $19 \%$ dan meningkat pada kelahiran ke 2 yaitu sekitar $79 \%$. Hal ini dikarenakan adanya pengaruh genetik, kualitas dan kuantitas pakan yang tersedia serta bangsa dari ternak tersebut. Beberapa penelitian menyebutkan juga bahwa dengan meningkatnya umur induk, maka tingkat ovulasi cenderung meningkat pula sehingga dimungkinkan dengan meningkatnya umur induk maka akan diikuti dengan meningkatnya litter size (Siwa, 2002).

Secara genetik ternak kambing betina dapat melahirkan lebih dari 1 anakdalam 1 kali melahirkan (prolifik), terutama pada kelahiran kedua, ketiga dan seterusnya.Tingkat konsumsi pakan juga berpengaruh terhadap litter size, dimana pemberian pakan dengan taraf nutrisi yang lebih tinggi pada saat menjelang ovulasi akan meningkatkan jumlah ovum yang akan diovulasikan (Inounu, 1996). Induk Kambing Kacang pada umumnya memiliki kemampuan melahirkan anak lebih dari satu ekor dan secara teori seekor induk kambing dapat beranak 3 kali dalam 2 tahun sehingga kid crop Kambing Kacang dapat melebihi 100\% (Sutama et al (1996).

\section{Angka Kelahiran Cempe}

Produktivitas induk merupakan kemampuan induk untuk menghasilkan anak. Hasil penelitian menunjukkan bahwa jumlah cempe yang lahir terbanyak dalam kurun waktu 1 tahun terdapat pada Kecamatan Asera sebanyak 86 ekor, kemudian Lasolo 84 ekor dan Kecamatan Molawe sebanyak 52 ekor. Tingginya jumlah cempe yang lahir pada Kecamatan Asera dan Kecamatan Lasolo dibandingkan dengan Kecamatan Molawe disebabkan karena jumlah induk yang melahirkan kembar 2dan 3 memiliki jumlah yang tinggi dibandingkan dengan Kecamatan Molawe yang hanya memiliki jumlah induk tertinggi pada kelahiran tunggal.

Tingginya jumlah angka kelahiran cempe kembar 2 dan 3 pada Kecamatan Lasolo dan Kecamatan Asera juga mungkin disebabkan oleh adanya pengaruh lingkungan serta padang penggembalaan yang tersedia masih cukup luas sehingga hijauan makanan ternak bagi ternak yang akan digembalakan masih cukup banyak tersedia. Hal ini sesuai dengan pendapat yang dikemukakan oleh Haryanto dan Djajanegara (1993) bahwa Lingkungan mempengaruhi angka kelahiran setiap tahun sehingga musim dapat berpengaruh secara nyata. Kelahiran kembar dapat meningkat pada musim-musim tertentu. Hal ini disebabkan karena pastura yang lebih baik pada musim tertentu (musim hujan).

\section{Angka Kematian Cempe}

Angka mortalitas cempe yang terendah pada penelitian ini diperoleh pada Kecamatan Molawe sebesar 9,61\% dengan jumlah ternak yang mati yaitu sebanyak 5 ekor. Kecamatan Asera diperoleh mortalitas cempe sebesar 10,46\% dengan jumlah cempe yang mati sebanyak 9 ekor sedangkan Kecamatan Lasolo diperoleh mortalitas cempe sebesar 20,24\% dengan jumlah cempe yang mati yaitu sebanyak 17 ekor. Rataan mortalitas cempe Kambing Kacang di Kabupaten Konawe Utara adalah sebesar 13,96\%. Rataan mortalitas cempe yang diperoleh pada penelitian ini sangat berbeda jauh dengan persentase mortalitas cempe yang dilaporkan oleh Sukendar et al., (2005) bahwa angka kematian anak kambing Peranakan Etawah (PE) prasapih adalah 9,3\% dari total anak yang dilahirkan $(4,56 \%$ dari total populasi). Tingginya persentase mortalitas cempe terutama pada Kecamatan Lasolo ini disebabkan karena adanya penyakit yang menyerang ternak seperti penyakit kutu dan cacingan yang tidak bisa di kendalikan khususnya ketika memasuki musim penghujan, kurangnya 
perhatian peternak terhadap ternak yang sakit, kurangnya pakan (susu induk), cempe yang lahir lemah (pada usia prasapih 0-3 bulan).

Penyakit yang menyerang ternak seperti penyakit kutu dikarenakan ternak yang dipelihara oleh peternak semuanya dikandangkan dalam satu kandang yang sama sehingga penyakit kutu yang diderita oleh salah satu ternak tersebut dapat berpindah keternak yang lainnya. Penyebab kematian ternak kambing yang disebabkan oleh kurangnya perhatian peternak terhadap ternaknya yang sakit yaitu karena tindakan pengobatan yang dilakukan masih bersifat tradisional sehingga proses kesembuhan ternak tidak terjamin.

\section{Panen Cempe (kid crop)}

Berdasarkan data pada Tabel 1, diperoleh rataan panen cempe penelitian ini sebesar 167,71\%. Angka panen cempe untuk Kecamatan Asera sebesar 200,93\% lebih tinggi dibandingkan angka panen cempe di Kecamatan Lasolo dan Kecamatan Molawe yang masing-masing sebesar $163,97 \%$ dan $138,24 \%$.

Tingginya nilai panen cempe di lokasi penelitian seperti pada Kecamatan Asera, disebabkan karena jumlah pakan yang tersedia masih cukup banyak, tingginya litter size (Tabel 1), rendahnya persentase kematian (Tabel 1), serta rendahnya interval kelahiran. Semakin tinggi nilai litter size maka semakin tinggi pula nilai panen cempe yang diperoleh, dan sebalikya semakin rendah nilai mortalitas cempe prasapih maka dapat meningkatkan angka panen cempe.

Aspek pakan juga mempunyai pengaruh yang sangat besar yaitu sekitar $60 \%$ terhadap produksi ternak kambing, selain faktor lingkungan. Hal ini berarti bahwa walaupun potensi ternak tinggi, akan tetapi jika pakan yang diberikan tidak memenuhi persyaratan kulitas dan kuantitas, maka produksi ternak akan rendah.
Nilai panen cempe yang diperoleh pada lokasi penelitian dengan yang diperoleh oleh para peneliti sebelumnya tidak berbeda jauh. Ngadiyono et al.,(1984) mendapatkan nilai panen cempe kambing lokal di daerah Ngaglik dan Imogiri yaitu sebesar 134,37\%. Panen cempe kambing Peranakan Etawah (PE) di zona tinggi yaitu $178,15 \%$ dan $164,28 \%$ di zona sedang (Widi, 2002). Basuki et al., (1981) mendapatkan panen cempe kambing Bligon sebesar $125 \%$ dan kambing Peranakan Etawah (PE) sebesar 118,25\%. Selanjutnya hasil penelitian Aka (2008), diperoleh angka panen cempe Peranakan Etawah (PE) sebesar $225,7 \%$.

\section{KESIMPULAN}

Dari hasil penelitian ini dapat disimpulkan bahwa nilai panen cempe Kambing Kacang di Kabupaten Konawe Utara adalah $167,71 \%$ dengan interval beranak (kidding interval) selama 8,61 bulan dan jumlah anak sekelahiran (litter size) sebanyak 1,36 ekor. . Sedangkan angka kematian anak (mortalitas) cempe mencapi 13,96\%. Secara keseluruhan dapat dikatakan bahwa produktivitas reproduksi ternak Kambing Kacang di Kabupaten Konawe Utara masih cukup baik.

\section{DAFTAR PUSTAKA}

Aka, R. 2008. Produktivitas induk dan panen cempe kambing peranakan etawah pada pola pemeliharaan sistem kandang kelompok dan kandang individu di kecamatan turi kabupaten turi provinsi daerah istimewa yogyakarta. J. Ilmu-ilmu Pertanian, 2(4):25-31.

BadanPusat Statistik, 2009.Sulawesi Tenggara dalam Angka 2008, Sulawesi Tenggara. Kendari.

Basuki, P., W. Hardjosubroto, dan N. Ngadiyono. 1981. performans produksi dan reproduksi kambing peranakan etawah (PE) dan bligon. Procceding Pertemuan Ilmiah Ruminansia Kecil. Pusat Penelitian dan Pengembangan 
Peternakan, Badan Penelitian dan Pengembangan Pertanian

Devendra C. dan M. Burns., 1994. Produksi Kambing di Daerah Tropis, Penerbit ITB, Bandung.

Djoharjani, T. Nuryadi, B. Hartono, M. Nasich dan Hermanto. 1993. Potensi dan sistem produksi ternak kambing, studi kasus integrasi kambing dan kebun kopi di jawa timur. Prosiding Lokakarya Potensi dan Pengembangan Ternak Kambing di Wilayah Indonesia Timur.

Haryanto, B. dan A. Djajanegara, 1993. Kebutuhan Nutrisi Ruminansia Kecil. Dalam: Produksi Kambing dan Domba di Indonesia. Sebelas Maret University Press, Surakarta.

Inounu, I. 1996. Keragaman Produksi Ternak Domba Prolifik. Disertasi. Pascasarjana Institut Pertanian Bogor. Bogor.

Ngadiyono, N., P. Basuki dan G. Murtijo. 1984. Beberapa data performans ternak kambing yang dipelihara secara tradisional di pedesaan sejak lahir sampai dengan umur disapih. Proceeding Pertemuan Ilmiah Penelitian Ruminansia Kecil. 22-23 November. Pusat Penelitian dan Pengembangan Peternakn. Bogor. Hal :122-125.

Siwa, I.P., Subandriyo, M. Martawidjaja, D. Priyanto, D. Yulistiani, T. Sartika, B. Tiesnamurti, K. Diwyanto dan L. Praharani. 2002. Evaluasi Peningkatan Produktivitas Kambing Persilangan. Kumpulan Hasil-Hasil Penelitian Peternakan APBN TA. 1999/2000. Buku 1. Penelitian Ternak Ruminansia Kecil. Balitnak, Puslitbangtan, Bogor, Pp: 157178.

Subandriyo, B. Setiadi and P. Sitorus. 1986. Ovulation rate and litter size of Indonesian goats. Proc. 5th Int. Conf. Livestock Production and Deseases in The Tropic. Kuala Lumpur, Malaysia, Pp: 5354.

Sukendar, A., Duljaman, dan A. Sukmawati. 2005. Potensi reproduksi dan distribusi dalam pengembangan kambing pe di desa hegarmanah kecamatan cicantayan kabupatenn sukabumi jawa barat. Media
Peternakan. Fakultas Peternakan IP. Bogor, 11(5):1-7.

Sumadi, 2001. Estimasi dinamika populasi dan output kambing peranakan etawah di kabupaten kulonprogo. Buletin Peternakan, 25(4):161-171.

Sutama, I.K., B. Setiadi, I.G.M. Budiarsana, T. Kostaman, A. Wahyuarman, M.S. Hidayat, Mulyawan, R. Sukmana dan Bachtiar. 1996. Pembentukkan kambing Persilangan Boereta Untuk Meningkatkan Produksi Daging dan Susu. Laporan Hasil Penelitian, Balai Penelitian Ternak.

Widi, T.S.M,. 2002. Kinerja induk kambing dan domba pada tiga zona agro yang berbeda di kabupaten kulonprogo. Tesis. Program Pascasarjana Universitas Gadjah Mada.Yogyakarta. 